pulse, upon which the author lays stress, is an important factor in this more peculiarly psychic adaptation also. It is possibly one of the important conditions leading up to the readjustment of tactual and visual local signs, by which a new tactual locality comes to feel as if it actually were the true counterpart of a visual place to which it does not belong. But the change of the motor impulse is not this psychic adaptation itself; as is proved by the altogether different amount of time and practice which each requires for its production.

In contrasting his own results with Helmholtz's, the author makes a curious slip. He quotes Helmholtz's account that when one hand has become accustomed to react suitably with the prism before the eyes, and then the eyes be closed, any object which we have localized with that hand can now be unerringly found with the other-the unaccommodated-hand, showing that the process of accommodation had not given a false color to the muscular feelings in the adapted hand. Reddingius then goes on to say that when he himself used a prism whose refractive angle was $36^{\circ}$ (as against $16^{\circ}$ or $18^{\circ}$ in those of Helmholtz) he got quite the opposite result: the unaccommodated hand also went astray. 'Yet this 'opposite result,' one finds, was obtained while onc cye was open and looking through the prism! The fact is that, with either wcaker or stıonger prisms (the reviewer finds), one can get Helmholtz's result or its real opposite, according as the unpracticed hand, on closing the eyes, is guided by a visual or by a muscular memory of the locality sought. Guided by the memory of the impression obtained the moment before through the prism, the hand goes astray; guided, however, by the dying feeling in the accommodated hand when last it touched the object, the other hand finds the place exactly. This, however, is quite in keeping with Reddingius' conclusion that the abnormality in the movement only occurs in connection with optical presentations. Movements whose startingpoint and goal are figured entirely in muscular terms are not affected by the 'adaptation.'

UNIVERSITY OF CALIFORNIA.

George M. Stratton.

\title{
EDUCATIONAL PSYCHOLOGY.
}

Kritische Untersuchungen iber Denken, Sprechen, und Sprachunterricht. A. Messer. Schiller and Ziehen's Abhandlungen, III. Bd., $6 \mathrm{Heft}$. 1900.

Dr. Messer's monograph is a critical discussion of the value of classical studies. It takes its departure from the antagonistic results 
arrived at by two men who have recently written upon the importance of linguistic study. ${ }^{1}$

Of these, the former holds that no better means than language study can be found for the material enrichment as well as the formal discipline of the mind; the latter considers it unadapted to accomplish either end. Both appreciations-the low as well as the high-are connected with special theories of the psychological significance of verbal signs on the part of these authors.

According to Keller, words do not signify things themselves, but our ideas of things, of relations, of movements, and our concepts. They stand for a peculiarly subjective range of experiences, which cannot be apprehended by observations of the objects with which they are secondarily connected, but must be directly communicated through these symbols themselves. Were words but the signs of things the acquisition of a foreign tongue would have little bearing upon the mental development of the learner. Being nothing of the kind, but rather symbols of a most strongly individualized conceptional way of regarding these things, the significant word becomes a new material element in the learner's thought content. To acquire an unfamiliar speech is not merely to learn a novel set of signs for the same old world; it is to win a fresh spiritual possession and vastly to enrich the material of our mental life.

In reply to this Messer very briefly and conclusively points out that the foreign word, heard for the first time, is a bare sound or visual impression, and that it takes on intelligible content only when there has been connected with it one or more words of one's mother-tongue or the perception of the object which it-directly or indirectly-indicates. It takes on meaning only through its translation into terms of an intuition of our own culture-world, in which process no material enrichment is gained. Such a widening of our spiritual horizon can take place first when a study of the literature of a foreign people has been added to that of its speech, and, indeed, even this becomes effective only when richly supported by information concerning the actual conditions of their material and social life.

For Ohlert also the term fails to represent the thing, but for a different reason than that of Keller. The word, he says, is thoroughly and aiways one-sided. It indicates not the sum of characteristics which actually constitutes the object, but only that one of these which attracted the attention of the name. The word Bojs, for example, seizes

1 'Denken und Sprechen und Sprachunterricht.' Julius Keller, Lorrach, I899. 'Das Studum der Spracluen und die geistıge Bildung.' Aruold Ohlert, Berlin, I899. 
upon only one of the many aspects which the ox presents, and characterizes it as the bellowing beast. Or again, letting slip all thought of the wolf's size, color, form, gait, and a thousand other things, we apperceive him only as the Render, not even creating a new verbal element, but only applying a special already existing root-wood.

But all this, it is objected by our author, applies only to the original naming of the beasts, and in no way holds of the speech of any cultured people. The specialized apperception which gave birth to the verbal form is but one of a vast range of possible aspects and relations which the thing may possess, all of which are implicit in the term. For the word does indicate the object and all its characteristics, however the ideational content which it arouses may vary in passing from the child to the adult, or from one special practical relation to another. And just because the term signifies for our consciousmess not a single characteristic, but the object at large-or rather a whole class of objects-the utterance of a word, apart from the connections of rational speech, may arouse a whole series of images in cunsciousness, which renders it impossible to determine in advance what particular course the reproduction will follow in any given case.

Nor is Ohlert's second point better taken. namely, that we customarily employ verbal symbols without having in mind the characteristics which they indicate. The term 'unconscious' here is unhappily chosen; it can signify only 'beyond the focus' and not below the threshold' of consciousness. And even so, it can mean only that in hearing and reading intelligent language there is not aroused in us a specific awareness of the many concrete aspects and relations under which the thing may be conceived, but only a faint fringe of feeling concerning the existence of other meanings and applications which we could realize if we wished. Yet here we must remember that in all connected speech the particular content is really quite definitely determined, and a departure from it-the appearance of ambiguities or arbitrary associations-is the exception, not the rule. The truth lies between these two extremes. The learning of a foreign language does not enrich the mind with a new range of material knowledge, but it is not on that account the less valuable as a part of school instruction. Ohlert's assertion that capacity for right judgment and training in logical thought is to be gained only by the process of thoroughly acquainting ourselves with the concepts and objects about which such judgments are made simply cannot be maintained.

The acquisition of a rich material knowledge is undoubtedly an important part of education. But no less significant is that whole 
group of studies which direct the pupil's attention to the activity of thought itself, and call upon him to analyze the nature of the concepts which he constantly employs, to discriminate and compare their applications, and to practice the process of thought so that, in the words of Paulsen, he may be able clearly to separate and apprehend the problems of thought relations. And for this logical training the study of foreign languages, in virtue of its unremitting demand for comparison with the verbal concepts of its mother-tongue, offers a rich and appropriate material.

\section{R. MacDougall.}

Harvard University.

\section{PSYCHOPHYSICAL.}

Quelques contributions à la psychologic du sommeil chcz les sains de esprit et chez les aliénes. By Alexandre Pilcz. Annaleg Mèdico-Psychologiques. Vol. LVII., No. I., Jan.-Feb., I899. Pp. 66-75.

Dr. Pllcz, assistant in the first psychiatrical clinic of Vienna, gives in this interesting and clearly written paper the results of experiment on himself and of inquiry among competent patients. The monotonous life of the hospital made it possible for him to retire to sleep on the moment, as he says, and he arose regularly at seven in the morning. Before going to bed, during a period of several weeks, he took doses of bromide, of paraldehyde, tea, alcohol, etc., or else subjected himself to severe physical or mental labor. On awakening he wrote out his dream-experiences and likewise the content of his consciousness whenever awakening during the night, which was a frequent occurrence.

He states that he was entirely unable to verify the results reported by Nelson (Am. Jour. Psy., Vol. I.) as to an alleged periodicity or regularity of the intensity of his dreams, although he devised a scale by which the subjective intensity could be in each case accurately recorded.

During the nights when he was under the influence to a greater or less extent of excitants, such as tea, coffee, alcohol, exciting events or of intellectual or emotional experiences such as the opera, his dreams were short and confused, and they related to recent and relatively un important events. When, on the other hand, he had taken paralde- 